\title{
Ecto-5' -Nucleotidase (CD73) Inhibits Nociception by Hydrolyzing AMP to Adenosine in Nociceptive Circuits
}

\author{
Nathaniel A. Sowa, ${ }^{1,2}$ Bonnie Taylor-Blake, ${ }^{1}$ and Mark J. Zylka ${ }^{1,2}$ \\ ${ }^{1}$ Department of Cell and Molecular Physiology, UNC Neuroscience Center and ${ }^{2}$ Curriculum in Neurobiology, University of North Carolina at Chapel Hill, \\ Chapel Hill, North Carolina 27599
}

Ecto-5' -nucleotidase (NT5E, CD73) is a membrane-anchored protein that hydrolyzes extracellular adenosine $5^{\prime}$-monophosphate (AMP) to adenosine in diverse tissues but has not been directly studied in nociceptive neurons. We found that NT5E was located on peptidergic and nonpeptidergic nociceptive neurons in dorsal root ganglia (DRG) and on axon terminals in lamina II (the substantia gelatinosa) of spinal cord. NT5E was also located on epidermal keratinocytes, cells of the dermis, and on nociceptive axon terminals in the epidermis. Following nerve injury, NT5E protein and AMP histochemical staining were coordinately reduced in lamina II. In addition, AMP hydrolytic activity was reduced in DRG neurons and spinal cord of $N t 5 e^{-l-}$ mice. The antinociceptive effects of AMP, when combined with the adenosine kinase inhibitor 5-iodotubericidin, were reduced by $\sim 50 \%$ in $N t 5 e^{-1-}$ mice and were eliminated in Adenosine $A_{1}$ receptor $\left(A_{1} R\right.$, Adora1) knock-out mice. Additionally, $N t 5 e^{-I-}$ mice displayed enhanced sensitivity in the tail immersion assay, in the complete Freund's adjuvant model of inflammatory pain and in the spared nerve injury model of neuropathic pain. Collectively, our data indicate that the ectonucleotidase NT5E regulates nociception by hydrolyzing AMP to adenosine in nociceptive circuits and represents a new molecular target for the treatment of chronic pain. Moreover, our data suggest NT5E is well localized to regulate nucleotide signaling between skin cells and sensory axons.

\section{Introduction}

Nucleotides play fundamental roles in pain mechanisms (Tsuda et al., 2005; Burnstock, 2007; Sawynok, 2007; Dussor et al., 2009). Nucleotides are released extracellularly by sensory neurons, skin keratinocytes, and other cell types. Nucleotides then activate purinergic receptors and cause pain, in part, by exciting and sensitizing nociceptive (pain-sensing) neurons in DRG. The excitatory effects of nucleotides can be terminated by membrane-bound and secreted ectonucleotidases (Zimmermann, 2006). Ectonucleotidases dephosphorylate extracellular ATP, ADP, and AMP to adenosine. Adenosine has well studied inhibitory and antinociceptive effects that are dependent on $\mathrm{A}_{1} \mathrm{R}$ activation (Sawynok, 2007). Ectonucleotidases thus have the capacity to convert pronociceptive nucleotides into antinociceptive adenosine.

For $>40$ years, it was known that DRG neurons and their axon terminals in dorsal spinal cord contained one or more ectonucleotidases that could generate adenosine by hydrolyzing the $5^{\prime}$ -

\footnotetext{
Received 0ct. 27, 2009; revised Dec. 27, 2009; accepted Jan. 2, 2010.

This work was supported by grants to M.J.Z. from The Searle Scholars Program, Rita Allen Foundation, and National Institute of Neurological Disorders and Stroke (NINDS) (R01NS060725, R01NS067688). N.A.S. was supported by NINDS (F30NS063507) and a Medical Scientist Training Program grant (T32GM008719). Confocal imaging was performed at the University of North Carolina at Chapel Hill Confocal Imaging Facility, which is cofunded by NINDS and National Institute of Child Health and Human Development (P30NS045892). M.J.Z. is a Rita Allen Foundation Milton E. Cassel Scholar. We thank Linda Thompson for providing congenic Nt5 $e^{-1-}$ mice, Steven Tilley for providing congenic $A_{7} R^{-1-}$ mice, David J. Anderson for providing congenic Mrgprd $\Delta^{E G F P f}$ knock-in mice, and Yvette Chuang and Hong Wang for technical assistance.

Correspondence should be addressed to Mark J. Zylka, Department of Cell and Molecular Physiology, UNC Neuroscience Center, University of North Carolina at Chapel Hill, CB \#7545, Chapel Hill, NC 27599. E-mail: zylka@med.unc.edu.

DOI:10.1523/JNEUROSCI.5324-09.2010

Copyright $\odot 2010$ the authors $\quad 0270-6474 / 10 / 302235-10 \$ 15.00 / 0$
}

phosphate from extracellular AMP (Scott, 1967; Suran, 1974; Nagy and Daddona, 1985). Initially, this ectonucleotidase activity was visualized using enzyme histochemistry-a technique that entails incubating tissue sections with AMP and detecting a lead phosphate precipitate. Subsequently, the existence of ectonucleotidases in nociceptive neurons was supported by electrophysiological and pharmacological studies. Salter and Henry (1985) found that iontophoretic application of AMP inhibited noxious heat-evoked activity in most dorsal horn neurons and this inhibition was dependent on adenosine receptor activation. Likewise, Li and Perl (1995) found that extracellularly applied AMP evoked an adenosine receptor-dependent inhibitory current in lamina II neurons. Together, these data suggest the inhibitory effects of AMP might be due to extracellular hydrolysis to adenosine. In support of this, Patterson et al. (2001) used a push-pull microprobe to sample extracellular adenosine concentrations in rat dorsal spinal cord while delivering AMP. They found that AMP was hydrolyzed to adenosine and that this hydrolysis was partially blocked by $\alpha \beta$-methylene-ADP, a relatively selective inhibitor of an enzyme called ecto-5'-nucleotidase (NT5E, also know as CD73). This study provided indirect pharmacological evidence that NT5E might contribute to AMP hydrolysis in the spinal cord. Last, Patterson et al. (2001) found that spinally administered AMP reversed capsaicin-mediated allodynia (an antinociceptive effect) that was dependent on $A_{1} R$ activation.

Recently, we found that prostatic acid phosphatase (PAP, also known as ACPP or fluoride-resistant acid phosphatase) was expressed in nociceptive neurons and hydrolyzed AMP to adenosine (Zylka et al., 2008; Sowa et al., 2009). Interestingly, this AMP hydrolytic activity was reduced but not eliminated in tissues from 
$\mathrm{Pap}^{-1-}$ mice, suggesting additional AMP ectonucleotidases were present in nociceptive neurons. Here, using rigorous histochemical, genetic, and behavioral experiments we found that NT5E also contributes to AMP hydrolysis in nociceptive neurons.

\section{Materials and Methods}

Animals. All procedures and behavioral experiments involving vertebrate animals were approved by the Institutional Animal Care and Use Committee at the University of North Carolina at Chapel Hill. C57BL/6 mice were purchased from Jackson Laboratories. $N t 5 e^{-1-}$ (Thompson et al., 2004), $A_{1} R^{-1-}$ (Johansson et al., 2001; Hua et al., 2007), and Mrgprd $\Delta^{E G F P f}$ (Zylka et al., 2005) mice were backcrossed to C57BL/6 mice (Jackson) for 14, 12 , and 10 generations, respectively.

Tissue preparation. Adult male mice, $6-12$ weeks of age, were killed by decapitation. Lumbar spinal cord, DRG (L3-L5), and hindpaw skin were dissected and immersion fixed ( $8 \mathrm{~h}, 4 \mathrm{~h}$, and $3 \mathrm{~h}$ respectively) in $4 \%$ paraformaldehyde in $0.1 \mathrm{M}$ phosphate buffer, $\mathrm{pH}$ 7.4. Tissues were cryoprotected in $30 \%$ sucrose, $0.1 \mathrm{M}$ phosphate buffer, $\mathrm{pH} 7.3$ at $4^{\circ} \mathrm{C}$ for at least $24 \mathrm{~h}$, and frozen in OCT. DRG and skin were sectioned on a cryostat at $20 \mu \mathrm{m}$ and collected on Superfrost Plus slides. Slides were stored at $-20^{\circ} \mathrm{C}$ until use. Free-floating spinal cord sections were sectioned at 30 $\mu \mathrm{m}$ and immediately stained.

DRG neurons were cultured following a previously published procedure (Campagnola et al., 2008). Briefly, DRG from all rostral-caudal levels were collected and pooled from adult male mice and dissociated using collagenase ( $1 \mathrm{mg} / \mathrm{ml}$; Worthington, CLS1) and dispase $(5 \mathrm{mg} / \mathrm{ml}$; Invitrogen, 17105-041) in Hanks balanced salt solution (HBSS). Neurons were cultured on poly-D-lysine and laminin-coated glass coverslips in DH10 media (1:1 Hams F12/DMEM, 10\% fetal bovine serum, 1\% penicillin/streptomycin) with $25 \mathrm{ng} / \mathrm{ml}$ glial cell line-derived neurotrophic factor (GDNF; Millipore Bioscience Research Reagents, GF030) at $37^{\circ} \mathrm{C}$. GDNF was added to support the survival of small diameter nonpeptidergic DRG neurons (Molliver et al., 1997). Enzyme histochemistry was performed $72 \mathrm{~h}$ after plating.

Histology. Enzyme histochemistry was performed using 3 or $6 \mathrm{~mm}$ AMP as substrate and Tris-maleate buffer at pH 5.6 or 7.0, in the absence of detergent (Zylka et al., 2008). Immunofluorescence was performed as previously described (Zylka et al., 2008). Mrgprd-expressing neurons and axons were visualized by staining tissues from Mrgprd ${ }^{\text {EGFPf }}$ knock-in mice with antibodies to GFP (Zylka et al., 2005). Antibodies used included anti-NT5E (AF4488, R\&D Systems; 1:50 for DRG and skin and 1:100 for spinal cord), rabbit anti-CGRP (T-4032; Peninsula; 1:750 for DRG and spinal cord; 1:500 for skin), mouse anti-NeuN (MAB377, Millipore Bioscience Research Reagents; 1:250), rabbit anti-P2X3 (RA10109, Neuromics; 1:750), rabbit anti-TRPV1 (RA14113, Neuromics; 1:750), chicken anti-GFP (GFP-1020, Aves Labs; 1:600 for DRG and 1:750 for spinal cord and skin), rabbit anti-NF200 (AB1982, Millipore Bioscience Research Reagents; 1:500), and rabbit anti-PGP 9.5 (Ultraclone, 1:500). PAP was detected using chicken anti-mouse PAP (Taylor-Blake and Zylka, 2010; 1:4000) with amplification as described previously (Zylka et al., 2008).

Secondary antibodies and reagents included donkey antibodies coupled to Alexa fluorophores (Invitrogen; 1:200), rat anti-mouse IgG1FITC (Zymed/Invitrogen; 1:25), donkey anti-chicken IgY-Biotin (Jackson; 1:200), donkey anti-chicken IgY-FITC (Jackson; 1:200), and isolectin B4 (IB4)-Alexa 568 (Invitrogen; 1:100). DRAQ5 (Axxora; 1:10,000) was added to the secondary antibody mixtures when staining skin. Images were obtained using a Zeiss LSM 510 confocal microscope and collected as maximal projections.

Intrathecal injections. Adenosine 5'-monophosphate (AMP, $80 \mathrm{~mm}$ stock, Fluka, 01930) and 5-iodotubericidin (25 mM stock, Biomol, EI293) were dissolved in $0.9 \%$ saline and DMSO, respectively, and were then diluted in $0.9 \%$ saline before use. All drugs were intrathecally injected $(5 \mu \mathrm{l})$ into unanesthetized mice using the direct lumbar puncture method (Fairbanks, 2003).

Behavior. Male mice, 2-4 months old, were acclimated to the testing room, equipment, and experimenter for $1-3 \mathrm{~d}$ before behavioral testing. To further reduce variability, mice were almost exclusively tested when in the resting or light sleep behavioral state (Callahan et al., 2008). The experimenter was blind to genotype during behavioral testing. Noxious thermal sensitivity was measured by heating one hindpaw with a Plantar Test apparatus (IITC) following the Hargreaves method (Hargreaves et al., 1988). The radiant heat source intensity was calibrated so that a paw-withdrawal reflex was evoked in $\sim 10 \mathrm{~s}$, on average, in wild-type C57BL/6 mice. Cutoff time was $20 \mathrm{~s}$. One measurement was taken from each paw per day to determine paw withdrawal latency, with the exception of the AMP \pm ITU experiments, where measurements were made at the indicated time points after injection. In the tail-immersion assay, mice were gently restrained in a towel and the distal two-thirds of the tail was immersed in 46.5 or $49^{\circ} \mathrm{C}$ water. Latency to flick or withdrawal the tail was measured once per mouse. For the hot plate test, mice were placed on a metal surface heated at $52^{\circ} \mathrm{C}$ and latency to lick a hindpaw or jump was measured. Mechanical sensitivity was measured using semiflexible tips attached to an electronic von Frey apparatus (IITC) as described previously (Cunha et al., 2004; Inoue et al., 2004). The force values obtained with this apparatus are higher than the force values obtained using calibrated von Frey filaments (Inoue et al., 2004). Three measurements were taken from each paw (separated at $10 \mathrm{~min}$ intervals) then averaged to determine paw withdrawal threshold in grams. To sensitize mice [complete Freund's adjuvant (CFA) inflammatory pain model], $20 \mu \mathrm{l}$ of complete Freund's adjuvant (from MP Biomedicals) was injected into one hindpaw, centrally beneath glabrous skin, with a $30 \mathrm{G}$ needle. The spared nerve injury (SNI) model of neuropathic pain was performed as described previously (Shields et al., 2003).

\section{Results}

\section{NT5E is found on membranes of nociceptive neurons and} axon terminals in lamina II of dorsal spinal cord

NT5E is a glycophosphatidylinositol-anchored membrane protein that generates adenosine by dephosphorylating AMP extracellularly (Zimmermann, 1992). While NT5E regulates diverse physiological processes that are modulated by adenosine (Colgan et al., 2006), NT5E has never been directly studied in nociceptive neurons. To determine whether NT5E was expressed in nociceptive neurons, we performed double-label immunofluorescence with a commercially available anti-NT5E antibody and antibodies to various sensory neuron markers. We found that NT5E was primarily expressed in small- to medium-diameter DRG neurons, with particular enrichment on the plasma membrane and intracellular membranes (Fig. 1). High levels of NT5E were also found on the epineurium that surrounds dorsal root ganglia and peripheral nerves (data not shown). Nearly all (95.5 $\pm 1.1 \%$ ) $\mathrm{NT}^{2} \mathrm{E}^{+}$neurons expressed PAP (Fig. $1 A-C$; overlap quantified in Table 1), highlighting coincident expression of two molecularly distinct AMP ectonucleotidases. In addition, NT5E was found on almost all nonpeptidergic nociceptive neurons, as evidenced by extensive cellular overlap with the nonpeptidergic markers IB4, Mrgprd, and the nucleotide-gated ion channel P2X3 (Fig. $1 D-L$, Table 1). NT5E was also expressed in $38.0 \pm 2.4 \%$ of all peptidergic calcitonin-gene related peptide ${ }^{+}\left(\mathrm{CGRP}^{+}\right)$neurons and $18.9 \pm 2.4 \%$ of all TRPV ${ }^{+}$neurons (Fig. $1 M-R$, Table 1 ). TRPV1 is an ion channel that can be activated by capsaicin or noxious heat (Caterina et al., 1997). Few $(4.5 \pm 0.9 \%) \mathrm{NT}^{+} \mathrm{E}^{+}$ neurons expressed Neurofilament-200 (NF200), a marker of myelinated neurons (Fig. $1 S-U$, Table 1).

In the spinal cord, NT5E ${ }^{+}$axons terminated in lamina II (Fig. 2). Staining overlapped extensively with PAP, IB4, and Mrgprd (Fig. 2A-I) and partially overlapped with CGRP (Fig. $2 J-L$ ). Together, these studies suggest that NT5E is well localized to hydrolyze extracellular AMP in a subset of peptidergic and the majority of all nonpeptidergic nociceptive circuits. 

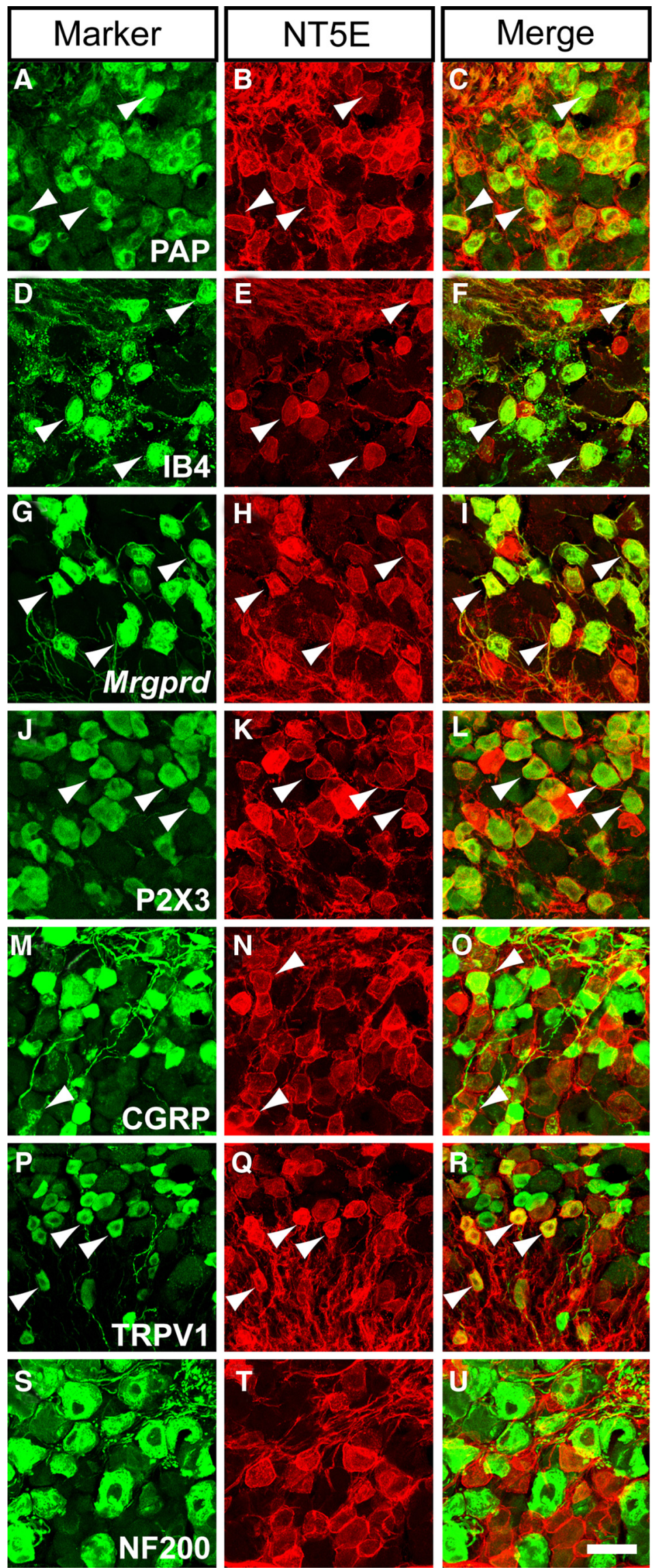

Figure 1. NT5E is found on most nonpeptidergic and some peptidergic nociceptive neurons. A-U, Mouse L3-L5 DRG neurons were stained for sensory neuron markers (green) and with antibodies against NT5E (red). Arrowheads mark examples
NT5E is found on free nerve endings in the epidermis and in cells of the skin Many peptidergic $\left(\mathrm{CGRP}^{+}\right)$and nonpeptidergic (IB4 ${ }^{+} / \mathrm{Mrgprd}^{+} /{\mathrm{P} 2 \mathrm{X} 3^{+}}^{+}$) nociceptive neurons terminate as free nerve endings in the epidermis, ideally positioning these neurons to sense noxious thermal and mechanical stimuli near the surface of the skin (Bennett et al., 1996; Bradbury et al., 1998; Wang et al., 1998; Lawson et al., 2002; Zylka et al., 2005; Cavanaugh et al., 2009; Rau et al., 2009; Taylor et al., 2009). Moreover, there is growing evidence that cells of the skin communicate with sensory neurons by releasing nucleotides extracellularly (Lumpkin and Caterina, 2007; Dussor et al., 2009). Since NT5E was coexpressed in nociceptive neurons that are known to project to skin, we next used immunostaining to determine whether NT5E was found in nerve endings or skin cells in glabrous and hairy skin. NT5E was extensively colocalized with PGP 9.5, a pan-neuronal marker of peripheral nerve fibers (Rice et al., 1997), and with $M r g p r d \Delta^{E G F P f}$, a genetically encoded axonal tracer that marks nonpeptidergic endings (Fig. 3A-F; supplemental Figs. S1, S2, available at www.jneurosci.org as supplemental material) (Zylka et al., 2005). Although NT5E and CGRP were colocalized to some extent in DRG neurons, we rarely found NT5E colocalized with CGRP in epidermal free nerve endings (Fig. $3 G-I$ ). Instead, $\mathrm{NT}^{+} \mathrm{E}^{+} / \mathrm{CGRP}^{+} \mathrm{fi}^{-}$ bers were found around and coursing along blood vessels in the deeper layers of skin (data not shown), suggesting $\mathrm{NT} \mathrm{E}^{+} / \mathrm{CGRP}^{+}$neurons target other end organs. In addition, high levels of NT5E were found on the plasma membrane of cells throughout the dermis, with dense cellular labeling in the superficial dermis (Fig. 3; supplemental Figs. S1, S2, available at www.jneurosci.org as supplemental material). Low levels of NT5E were present on keratinocytes throughout the epidermis, with staining most prominent on keratinocytes in the stratum basalis (supplemental Fig. S1B,C, available at www.jneurosci.org as supplemental material). NT5E was not uniformly distributed in the epidermis but instead was patchy, with strongest staining on keratinocytes of weight-bearing volar foot pads (data not shown). NT5E expression is upregulated under hypoxic conditions (Synnestvedt et al., 2002; Ledoux et al.,

of double-labeled cells. Images were acquired by confocal microscopy. Scale bar: (in $\boldsymbol{U}) \boldsymbol{A}-\boldsymbol{U}, 50 \mu \mathrm{m}$. 
2003), so this patchy distribution could reflect different metabolic demands in weight-bearing and non-weight-bearing regions of skin. Last, NT5E was also found at high levels on cells that make up the hair follicles, cells in the sweat gland, cells lining the sweat duct, and the epineurium of peripheral nerves that course through the skin (supplemental Fig. S2, available at www. jneurosci.org as supplemental material; data not shown).

For all experiments described above, NT5E antibody specificity was confirmed by the absence of staining when primary antibody was excluded and by the absence of staining in tissue sections (DRG, spinal cord, skin) from $N t 5 e^{-/-}$mice (supplemental Fig. S3, available at www.jneurosci.org as supplemental material).
Table 1. Quantitative analysis of NT5E and sensory neuron marker colocalization within wild-type mouse L3-L5 DRG neurons

\begin{tabular}{lll}
\hline Marker & $\begin{array}{l}\text { Percentage of NT5E }{ }^{+} \text {neurons } \\
\text { expressing indicated marker }\end{array}$ & $\begin{array}{l}\text { Percentage of marker }{ }^{+} \text {neurons } \\
\text { expressing NT5E }\end{array}$ \\
\hline PAP & $95.5 \pm 1.1$ & $82.7 \pm 1.5$ \\
IB4 & $83.6 \pm 2.6$ & $87.4 \pm 2.5$ \\
Mrgprd & $74.9 \pm 1.4$ & $98.5 \pm 0.3$ \\
P2X3 & $89.3 \pm 1.0$ & $82.3 \pm 1.9$ \\
CGRP & $44.6 \pm 3.6$ & $38.0 \pm 2.4$ \\
TRPV1 & $18.9 \pm 2.4$ & $26.1 \pm 3.0$ \\
NF200 & $4.5 \pm 0.9$ & $4.4 \pm 0.9$ \\
NeuN & 100 & $40.2 \pm 1.3$
\end{tabular}

Ganglia from three adult mice and $n>900$ cells were counted per marker combination. Data are means \pm SEM.
NT5E protein and AMP hydrolytic activity are reduced in lamina II of spinal cord following nerve injury

Nerve injury can cause neuropathic pain and can dramatically alter protein levels in nociceptive neurons and spinal axon terminals (Campbell and Meyer, 2006). Indeed, expression and activity of PAP was reduced in DRG and spinal axon terminals following nerve injury (Colmant, 1959; Csillik and Knyihar-Csillik, 1986; Costigan et al., 2002; Davis-Taber, 2006). To determine whether NT5E protein and activity levels were similarly reduced following nerve injury, we unilaterally injured the peroneal and sural branches of the sciatic nerve, using the SNI model of neuropathic pain (Shields et al., 2003), then stained serial adjacent lumbar spinal cord sections using AMP histochemistry and immunofluorescence. Following nerve injury, AMP hydrolytic activity was reduced and NT5E immunoreactivity was absent in the regions of lamina II that received inputs from the transected peroneal and sural nerves (Fig. 4A,B) (Shields et al., 2003). IB4 binding was also abolished in these regions (Fig. 4C,D), consistent with previous studies (Casals-Díaz et al., 2009). No changes were evident on the contralateral, uninjured side (Fig. 4).

\section{NT5E hydrolyzes AMP in nociceptive circuits}

Next, to directly test whether NT5E hydrolyzes AMP in nociceptive circuits, we stained DRG and spinal cord sections from wild-type (WT) and Nt5e $e^{-1-}$ mice using AMP histochemistry. Nt5e $e^{-l-}$ mice lack NT5E catalytic activity but otherwise appear normal and produce average sized litters (Thompson et al., 2004). In WT DRG, the membrane covering the DRG (epineurium), small- to medium-diameter neurons and their axons were intensely stained at $\mathrm{pH} 7.0$ while large-diameter neurons were weakly stained (Fig. 5A). Strikingly, staining of small- to medium-diameter DRG neurons and axons was reduced in $N t 5 e^{-1-}$ mice while staining of large-diameter neurons was not altered (Fig. $5 B$ ). These reductions in staining were not due to developmental loss of small- to medium-diameter DRG neurons, as wild-type and $N t 5 e^{-1-}$ mice had equivalent percentages of $\mathrm{P} 2 \mathrm{X}^{+}$neurons and $\mathrm{CGRP}^{+}$neurons relative to all $\mathrm{NeuN}^{+}$neurons in lumbar ganglia (supplemental Table S1, available at www.jneurosci.org as supplemental material). Staining of the epineurium was also eliminated in $N t 5 e^{-1-}$ mice (Fig. $5 B$ ), consistent with expression of NT5E in this tissue (described above).

In the spinal cord, AMP histochemical staining at $\mathrm{pH} 7.0$ was noticeably reduced in lamina II of $N t 5 e^{-l-}$ mice (Fig. $5 C-F$ ), precisely where $\mathrm{NT}_{5} \mathrm{E}^{+}$axons terminate (Fig. $2 \mathrm{~B}$ ). This reduction in staining was not due to loss of axon terminals in the dorsal horn of $N t 5 e^{-1-}$ mice, as IB4-binding in lamina II and other dorsal horn markers did not differ between WT and $N t 5 e^{-1-}$ mice (supplemental Fig. S4, available at www.jneurosci.org as supplemental material). In addition, staining was reduced throughout the gray matter of spinal cord, suggesting NT5E is 

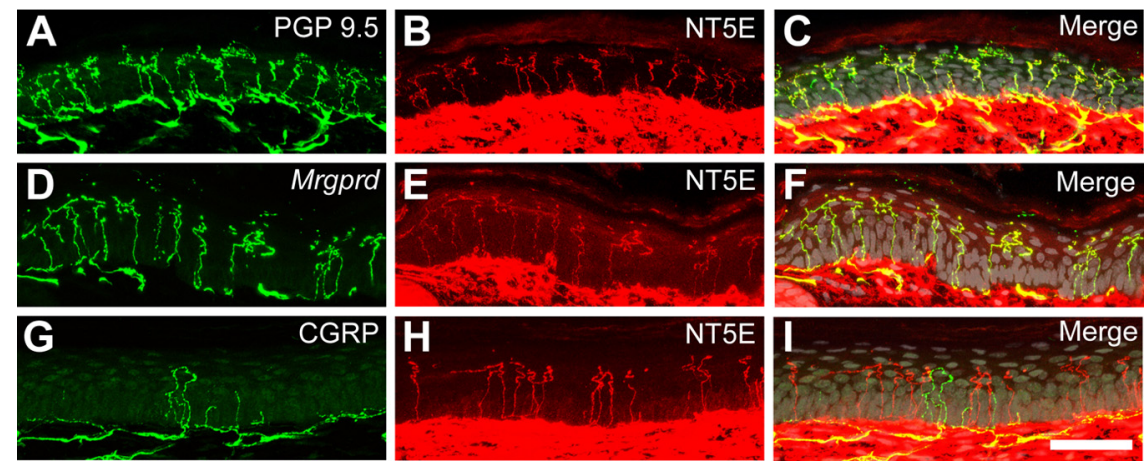

Figure 3. NT5E is primarily found in nonpeptidergic nerve terminals in the epidermis. $\boldsymbol{A}-\boldsymbol{I}$, Confocal images of mouse glabrous skin immunostained for NT5E (red) and the indicated markers (green). C, F, I, Nuclei were pseudocolored gray to highlight stratification of the epidermis. Scale bar: (in $\boldsymbol{I}) \boldsymbol{A}-\boldsymbol{I}, 50 \mu \mathrm{m}$.
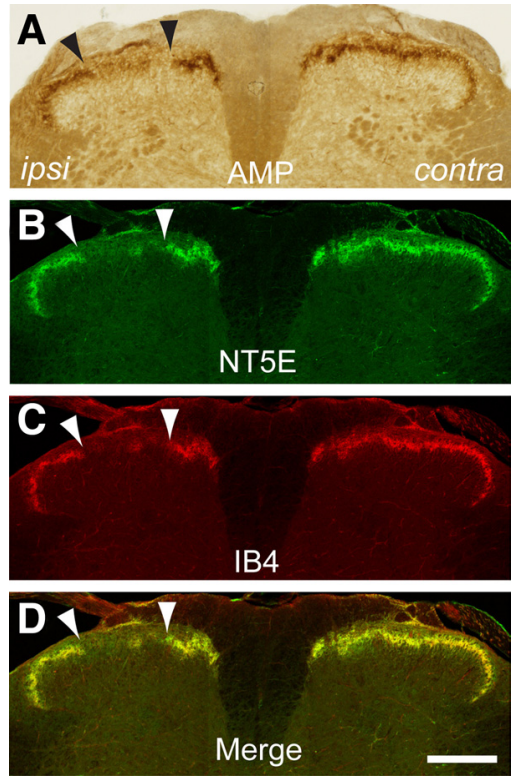

Figure 4. NT5E protein and AMP hydrolytic activity are reduced in axon terminals following peripheral nerve injury. $\boldsymbol{A}-\boldsymbol{D}$, Sections of lumbar spinal cord from a mouse killed $14 \mathrm{~d}$ after ligation and transection of the sural and common peroneal branches of the sciatic nerve (the SNI model). $\boldsymbol{A}$, Stained using AMP histochemistry (3 mM AMP; buffer pH was 7.0). $\boldsymbol{B}-\boldsymbol{D}$, An adjacent section labeled for the indicated markers. Arrowheads delimit the region of dorsal spinal cord where staining was reduced ipsilateral (ipsi) to the injured nerves. Contralateral (contra), uninjured side. Similar results were seen in $n=2$ mice. Scale bar: (in $\boldsymbol{D}) \boldsymbol{A}-\boldsymbol{D}, 200 \mu \mathrm{m}$.

expressed at low levels and contributes to AMP hydrolysis in neurons throughout the spinal cord. Last, minimal to moderate reductions in AMP histochemical staining were seen in DRG and spinal cord sections when histochemical staining was performed at pH 5.6 (supplemental Fig. S5A-F, available at www.jneurosci.org as supplemental material), the $\mathrm{pH}$ at which obvious reductions in AMP hydrolytic activity were seen in $\mathrm{Pap}^{-/-}$mice (Zylka et al., 2008).

To further demonstrate that NT5E hydrolyzed AMP extracellularly on sensory neurons and their axons, we cultured DRG neurons for $72 \mathrm{~h}$ to allow neurites to develop then histochemically stained these cultures in the absence of detergent (to maintain the integrity of the plasma membrane). In cultures from WT mice, AMP histochemical staining was predominantly on the soma and neurites of small- to medium-diameter DRG neurons (Fig. 5G). Staining of the soma was reduced and neurite staining was eliminated in cultures from $N t 5 e^{-1-}$ mice (Fig. $5 H$ ). Together, these histochemical studies with gene knock-out mice reveal that NT5E contributes to extracellular AMP hydrolysis on nociceptive neurons and axon terminals. Since staining was reduced but not eliminated in $N t 5 e^{-1-}$ mice, these data confirm that nociceptive circuits contain additional AMP ectonucleotidases that generate adenosine, one of which we previously identified as PAP (Zylka et al., 2008).

\section{Inflammation- and nerve}

injury-induced thermal hyperalgesia and mechanical allodynia are enhanced in $N t 5 e^{-1-}$ mice

$\mathrm{Pap}^{-1-}$ mice and $A_{1} R^{-1-}$ mice display enhanced nociceptive responses in animal models of chronic pain (Johansson et al., 2001; Wu et al., 2005; Zylka et al., 2008), suggesting deficiencies in adenosine production or adenosine signaling can be detected at the behavioral level. To determine whether Nt5e $e^{-l-}$ mice similarly show enhanced nociceptive responses, we tested agematched WT and Nt5e $e^{-1-}$ male mice using behavioral models of acute and chronic pain. We found no significant differences between genotypes using a measure of acute mechanical sensitivity (electronic von Frey) or two different measures of noxious thermal sensitivity (Hargreaves test and hotplate test at $52^{\circ} \mathrm{C}$ ) (Table 2). However, $\mathrm{Nt} 5 e^{-1-}$ mice had significantly shorter tail flick latencies in the tail immersion assay at both temperatures studied $\left(46.5^{\circ} \mathrm{C}\right.$ and $49^{\circ} \mathrm{C}$ ) (Table 2$)$. In addition, $N t 5 e^{-1-}$ mice had significantly enhanced thermal hyperalgesia and mechanical allodynia following inflammation of one hindpaw with CFA (Fig. $6 A, B)$. Moreover, $N t 5 e^{-1-}$ mice had significantly enhanced thermal hyperalgesia in the SNI model of neuropathic pain (Fig. $6 C, D$ ). In contrast, no significant differences were seen between genotypes in the control (non-inflamed/non-injured) paw using either chronic pain model (Fig. 6). Collectively, these studies reveal that $N t 5 e^{-I-}$ mice have enhanced nociceptive responses that are phenotypically similar to $A_{1} R^{-1-}$ and $P a p^{-1-}$ mice (Johansson et al., 2001; Wu et al., 2005; Zylka et al., 2008); summarized in supplemental Table S2, available at www.jneurosci.org as supplemental material.

\section{NT5E inhibits nociception by hydrolyzing AMP and} activating $A_{1} R$

Patterson et al. (2001) found that AMP was rapidly converted to adenosine when perfused in vivo over the dorsal spinal cord and reduced hyperalgesia caused by intradermal injection of capsaicin. This antinociceptive effect of AMP was dependent on $A_{1} R$ activation. Moreover, they found that hydrolysis of AMP to adenosine could be inhibited $\sim 50 \%$ by $\alpha \beta$-methylene-ADP, a relatively selective inhibitor of NT5E. Considering that this pharmacological inhibitor could have off-target effects in vivo (such as inhibition of other ectonucleotidases like PAP), or that the concentration used might not completely inhibit NT5E, we instead eliminated NT5E activity in a genetically precise manner, using $N t 5 e^{-1-}$ mice.

The push-pull microprobe used by Patterson et al. (2001) was optimized for use with rats, so we used the alternative approach of acute intrathecal injection of AMP to deliver AMP to DRG and spinal cord of mice. To our initial surprise, AMP alone (200 nmol) had no effect on noxious thermal sensitivity in WT mice (Fig. 7A), and higher doses were similarly without effect (data not shown). Moreover, AMP alone had no effect on noxious thermal sensitivity in $N t 5 e^{-1-}$ or $A_{1} R^{-1-}$ mice (Fig. $7 A$ ). We hypothe- 

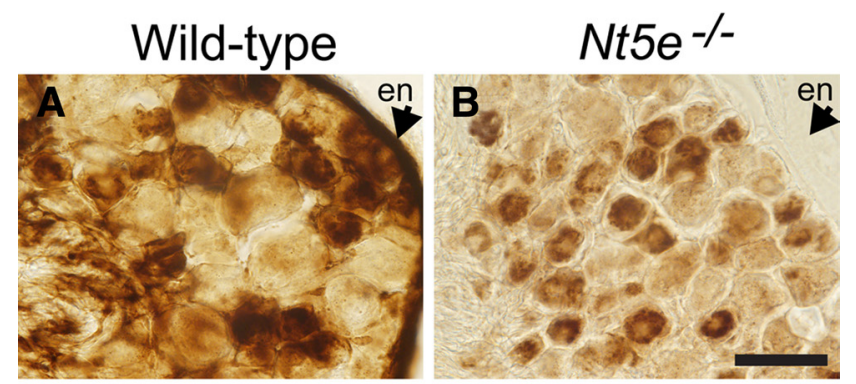

C

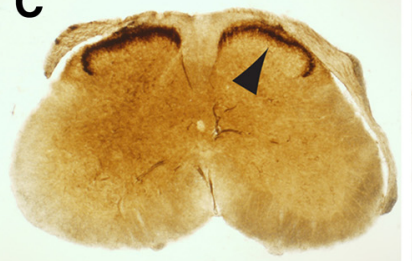

D
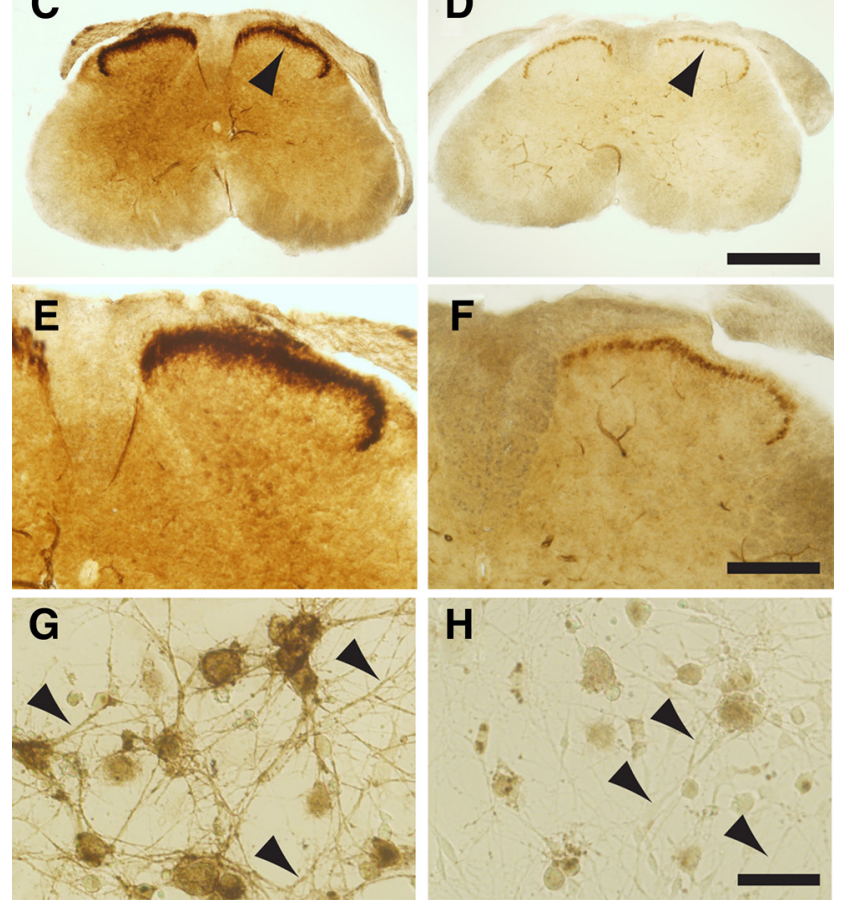

Figure 5. AMP hydrolytic activity is reduced in nociceptive circuits of $N t 5 e^{-1-}$ mice. $\boldsymbol{A}-\boldsymbol{H}$, Lumbar DRG $(\boldsymbol{A}, \boldsymbol{B})$, lumbar spinal cord $(\boldsymbol{C}-\boldsymbol{F})$ and cultured DRG neurons $(\boldsymbol{G}, \boldsymbol{H})$ from WT and $N t 5 e^{-/-}$adult mice stained using AMP histochemistry. Arrows point to epineurium (en). C, D, Arrowheads mark the location of axon terminals in dorsal spinal cord (lamina II). $\boldsymbol{E}, \boldsymbol{F}$, Higher magnification of $\boldsymbol{C}, \boldsymbol{D}$. G, $\boldsymbol{H}$, The plasma membrane was not permeabilized so that extracellular AMP hydrolytic activity could be assayed. Arrowheads point to neurites emanating from cultured neurons. AMP ( 6 mм in $\boldsymbol{A}, \boldsymbol{B}, \boldsymbol{G}, \boldsymbol{H}$ and $3 \mathrm{~mm}$ in $\boldsymbol{C}-\boldsymbol{F}$ ) was used as substrate, and buffer was pH 7.0. Scale bars: (in $\boldsymbol{B}, \boldsymbol{H}) \boldsymbol{A}, \boldsymbol{B}, \boldsymbol{G}, \boldsymbol{H}, 50 \mu \mathrm{m}$; (in $\boldsymbol{D}) \boldsymbol{C}, \boldsymbol{D}, 500 \mu \mathrm{m}$; (in $\boldsymbol{F}) \boldsymbol{E}, \boldsymbol{F}, 200 \mu \mathrm{m}$.

Table 2. Acute mechanical and thermal sensitivity in WT and $N t 5 e^{-/-}$mice

\begin{tabular}{|c|c|c|}
\hline \multirow[b]{2}{*}{ Behavioral assay } & \multicolumn{2}{|c|}{$\begin{array}{l}\text { Withdrawal threshold }(\mathrm{g}) \\
\text { or latency }(\mathrm{s})\end{array}$} \\
\hline & Wild-type & $N+5 e^{-/-}$ \\
\hline Electronic von Frey & $8.1 \pm 0.2 \mathrm{~g}$ & $7.7 \pm 0.2 \mathrm{~g}$ \\
\hline Radiant heating of hindpaw (Hargreaves method) & $10.6 \pm 0.3 s$ & $10.3 \pm 0.4 \mathrm{~s}$ \\
\hline Tail immersion at $46.5^{\circ} \mathrm{C}$ & $13.8 \pm 1.1 \mathrm{~s}$ & $9.5 \pm 0.5 \mathrm{~s}^{* *}$ \\
\hline Tail immersion at $49.0^{\circ} \mathrm{C}$ & $5.6 \pm 0.3 \mathrm{~s}$ & $4.2 \pm 0.2 \mathrm{~s}^{* *}$ \\
\hline Hot plate at $52^{\circ} \mathrm{C}$ & $29.4 \pm 2.1 \mathrm{~s}$ & $31.4 \pm 2.7 s$ \\
\hline
\end{tabular}

$n=10$ male mice tested per genotype. Data are expressed as means \pm SEM. Paired $t$ test was used to compare genotypes for each test, ${ }^{* *} p<0.005$.

sized this lack of an antinociceptive effect might be due to rapid degradation of ectonucleotidase-generated adenosine, resulting in insufficient levels of adenosine to activate $A_{1} R$. In an effort to increase the half-life of adenosine, we coinjected AMP with the adenosine kinase inhibitor 5-iodotubericidin (ITU). This inhibitor blocks the phosphorylation of adenosine to AMP and prolongs the half-life of extracellular adenosine (Kowaluk and Jarvis,
2000). When injected alone, ITU had no effect on noxious thermal sensitivity in any of the genotypes tested (Fig. $7 B$ ). However, paw withdrawal latency significantly increased in WT mice when AMP was combined with ITU, revealing a thermal antinociceptive effect (Fig. 7C). Strikingly, this thermal antinociceptive effect of AMP combined with ITU was reduced by $45 \pm 13.5 \%$ in $N t 5 e^{-1-}$ mice (based on quantifying the area under the curve relative to WT mice) and was eliminated in $A_{1} R^{-1-}$ mice. Together, these data indicate that the thermal antinociceptive effect of AMP combined with ITU was due to in vivo dephosphorylation of AMP to adenosine followed by activation of $A_{1} R$, with NT5E accounting for $\sim 50 \%$ of all AMP hydrolytic activity in DRG and spinal cord.

To further study the contribution of NT5E to AMP hydrolysis in vivo, we coinjected AMP with ITU in the setting of ongoing inflammation. After measuring baseline thermal sensitivity, we injected one hindpaw of WT and $N t 5 e^{-1-}$ mice with CFA to induce thermal hyperalgesia (Fig. 7D). One day later, the inflamed hindpaw of $N t 5 e^{-1-}$ mice displayed enhanced thermal hyperalgesia, reproducing our results above. We next coinjected (intrathecally) AMP with ITU then measured thermal sensitivity in the inflamed and non-inflamed (control) hindpaws. We found that AMP combined with ITU significantly reduced thermal hyperalgesia in the inflamed paw for $3 \mathrm{~h}$ in WT mice. In fact, withdrawal latency transiently returned to pre-CFA levels $30 \mathrm{~min}$. after injection of AMP with ITU. In contrast, the thermal antinociceptive effects of AMP combined with ITU were significantly blunted in duration and magnitude in $N t 5 e^{-1-}$ mice, both in the inflamed and non-inflamed paws (Fig. 7D). As controls, AMP alone (200 nmol, i.t.) and ITU alone ( $5 \mathrm{nmol}$, i.t.) had no effect on thermal sensitivity in the inflamed paws of WT and $N t 5 e^{-1-}$ mice (data not shown). Together, these data further show that NT5E reduces thermal nociception in vivo by hydrolyzing AMP to adenosine.

\section{Discussion}

Our previous studies with $\mathrm{Pap}^{-1-}$ mice suggested that nociceptive neurons contained additional ectonucleotidases that could hydrolyze AMP to adenosine (Zylka et al., 2008). Here, we found that NT5E is one of these additional enzymes. NT5E was found on DRG neurons, and primarily on the subset that expressed nociceptive neuron markers (IB4-binding, Mrgprd, CGRP, and TRPV1). In addition, NT5E was extensively coexpressed with PAP, suggesting that these two ectonucleotidases might coordinately metabolize AMP in nociceptive neurons under normal and pathological conditions, including inflammation where nucleotides and protons are released as part of the "inflammatory soup" (Julius and Basbaum, 2001). NT5E has a neutral pH optimum (Zimmermann, 1992), whereas PAP is catalytically active over a broader $\mathrm{pH}$ range ( $\mathrm{pH} 3-8)$ (Van Etten, 1982). Tissue acidosis could thus alter the relative contribution of PAP and NT5E to AMP hydrolysis. Indeed, AMP hydrolytic activity was clearly reduced in nociceptive neurons and spinal axon terminals of $N t 5 e^{-1-}$ mice at neutral $\mathrm{pH}$ but was less prominently reduced at an acidic $\mathrm{pH}$. In contrast, PAP has a more prominent effect on nucleotide hydrolysis at acidic pH (Vihko, 1978; Zylka et al., 2008; Sowa et al., 2009). NT5E and PAP were colocalized on axon terminals in lamina II and both proteins were downregulated following nerve injury (Colmant, 1959; Csillik and KnyiharCsillik, 1986; Costigan et al., 2002; Davis-Taber, 2006). This coordinate downregulation of enzymatically redundant proteins correlated with a loss of AMP hydrolytic activity in lamina II and could explain why nucleotide metabolism and $\mathrm{A}_{1} \mathrm{R}$ activity were 

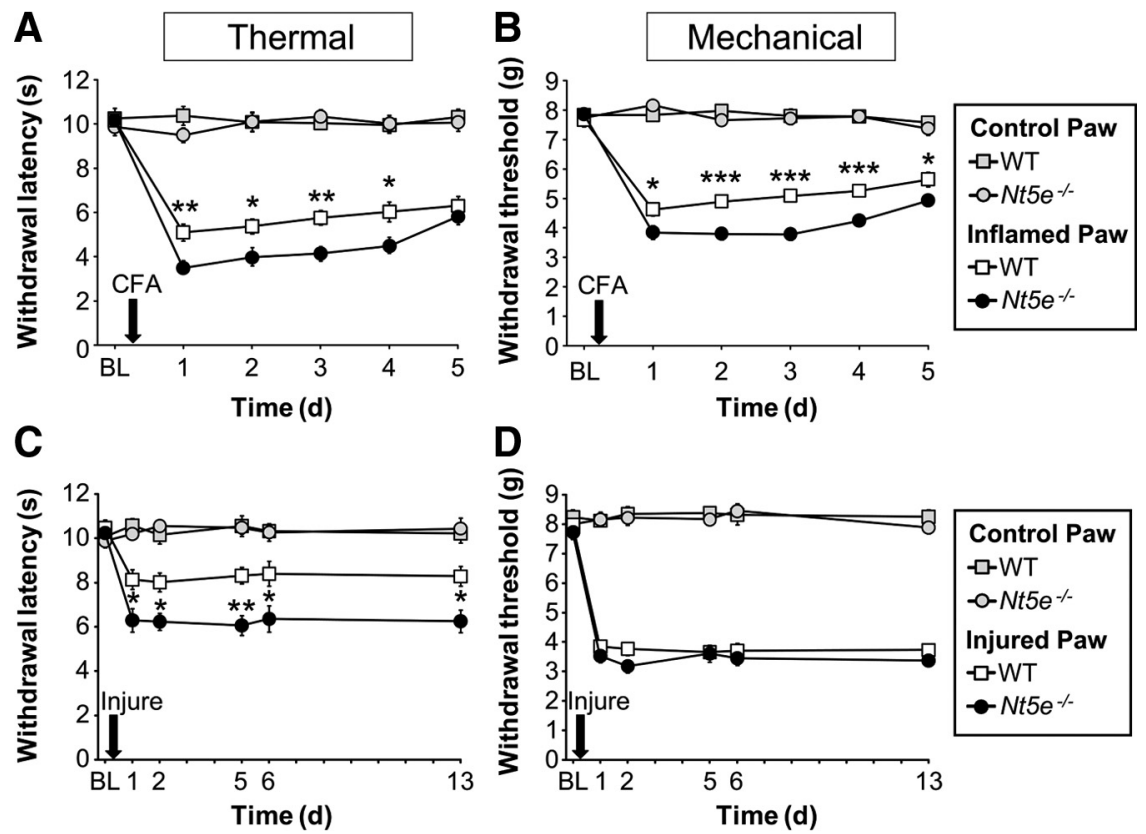

Figure 6. Nt5e $e^{-/-}$mice show enhanced nociceptive responses following inflammation and nerve injury. $\boldsymbol{A}, \boldsymbol{B}$, CFA inflammatory pain model. WT and $N+5 e^{-1-}$ mice were tested for $(\boldsymbol{A})$ thermal and $(\boldsymbol{B})$ mechanical sensitivity before $(\mathrm{BL})$ and following injection of CFA (arrow) into one hindpaw. The contralateral hindpaw served as control. C, D, SNI neuropathic pain model. WT and $N+5 e^{-I-}$ were tested for $(\boldsymbol{C})$ thermal and $(\boldsymbol{D})$ mechanical sensitivity before (BL) and after ligation and transaction of the sural and common peroneal branches of the sciatic nerve. $\boldsymbol{A}-\boldsymbol{D}$, Paired $t$ tests were used to compare responses at each time point between WT and $N t 5 e^{-1-}$ mice $\left(n=10\right.$ per genotype); same paw comparisons. ${ }^{*} p<0.05,{ }^{* *} p<0.005,{ }^{* * *} p<0.0005$. All data are presented as means \pm SEM.
A

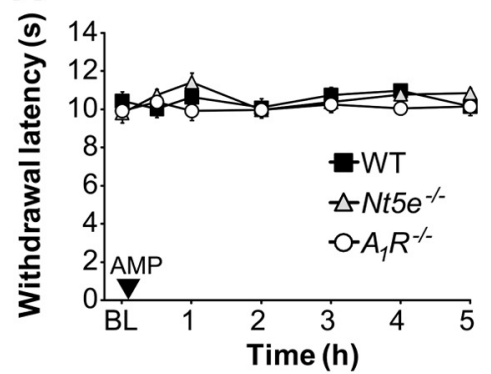

C

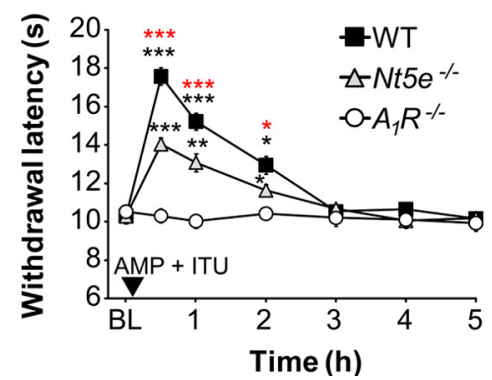

B

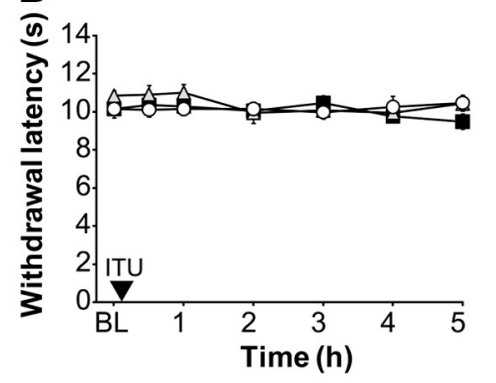

D

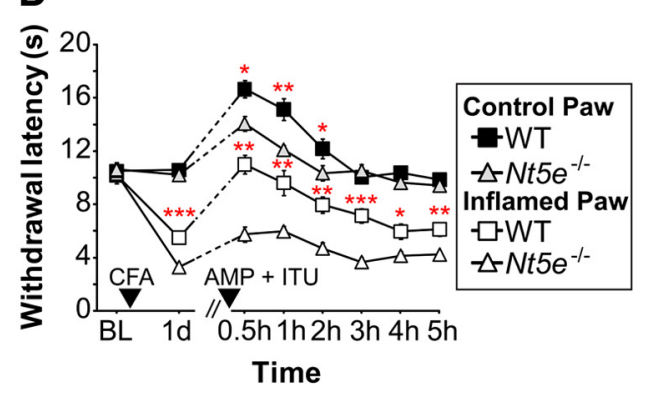

Figure 7. The antinociceptive effects of AMP $+I T U$ are reduced in $N t 5 e^{-1-}$ mice and are dependent on $A_{1} R$ activation. $\boldsymbol{A}, \boldsymbol{B}$, Noxious thermal sensitivity was measured before (baseline, BL) and after intrathecal injection of AMP (200 nmol) (A), ITU (5 nmol) $(B)$, or AMP ( $200 \mathrm{nmol})+$ ITU ( $5 \mathrm{nmol})$ (C). Paired $t$ tests were used to compare responses at each time point to BL values (black asterisks) within a given genotype ( $n=8$ mice per genotype). Paired $t$ tests were also used to compare responses at each time point between WT and $N t 5 e^{-l-}$ mice (red asterisks). D, Mice were tested for noxious thermal sensitivity before (BL) and after injection of (FA (arrowhead) into one hindpaw. The uninjected hindpaw served as control. One day later, all mice were injected intrathecally with AMP $(200 \mathrm{nmol})+$ ITU $(5 \mathrm{nmol})$ and thermal sensitivity was measured for several hours after injection. Paw withdrawal latencies were significantly elevated in both genotypes for up to $2 \mathrm{~h}$ following AMP + ITU injection, relative to the response $1 \mathrm{~d}$ after (FA injection (same paw comparisons). Paired $t$ tests were used to compare responses at each time point between WT and Nt5e $e^{-1-}$ mice (red asterisks; same paw comparisons). $n=8$ mice per genotype. ${ }^{*} p<0.05,{ }^{* *} p<0.005$, ${ }^{* * *} p<0.0005$. All data are presented as means \pm SEM. altered in DRG and spinal cord following nerve injury (Bantel et al., 2002; Matsuoka and Ohkubo, 2004).

$\mathrm{Nt} 5 \mathrm{e}^{-1-}, \mathrm{Pap}^{-1-}$, and $\mathrm{A}_{1} \mathrm{R}^{-1-}$ mice displayed enhanced thermal sensitivity and, in some genotypes, enhanced mechanical sensitivity in animal models of inflammatory and neuropathic pain $(\mathrm{Wu}$ et al., 2005; Zylka et al., 2008) (supplemental Table S2, available at www. jneurosci.org as supplemental material). Interestingly, the magnitudes of these enhanced sensory responses were similar in all three knock-out lines. A priori, one might predict that the magnitude of these enhanced sensory responses would be greater in $A_{1} R^{-1-}$ mice when compared with $N t 5 e^{-l-}$ or $\mathrm{Pap}^{-1-}$ animals since AMP hydrolytic activity (and hence adenosine production) was reduced but not eliminated in $\mathrm{N}_{5} \mathrm{e}^{-1-}$ or $\mathrm{Pap}^{-1-}$ animals. The similar phenotype in all three genotypes suggests either that these behavioral models lack the resolution to "report" intermediate levels of $A_{1} R$ activation or that reduced adenosine production and $A_{1} R$ signaling is as effective at enhancing nociceptive responses as complete elimination of $A_{1} R$ signaling.

Our findings also raise the question of why $N t 5 e^{-l-}, \mathrm{Pap}^{-1-}$, and $A_{1} R^{-l-}$ mice display enhanced nociceptive responses when sensitized. The most straightforward possibility is that these enhanced responses are due to reductions in adenosine production or $A_{1} R$ signaling. Transient $A_{1} R$ activation acutely inhibits neurotransmitter release from nociceptive neurons and inhibits postsynaptic neurons (Li and Perl, 1994; Lao et al., 2001; Patel et al., 2001). In contrast, ectonucleotidases like PAP hydrolyze nucleotides extracellularly and inhibit nociception by activating $A_{1} R$ over a sustained time period (Zylka et al., 2008). Sustained, ectonucleotidase-dependent activation of $A_{1} R$ could contribute to the underlying "adenosine tone" that regulates the level of excitability throughout the nervous system (Boison, 2008). Reductions or loss of this tonic $\mathrm{A}_{1} \mathrm{R}$ activation could contribute to enhanced nociceptive responses. Currently, it is unknown how sustained, ectonucleotidase-dependent activation of $A_{1} R$ inhibits nociception at a mechanistic level.

We also observed enhanced nociceptive responses in $N t 5 e^{-1-}$ mice to noxious thermal stimuli using the tail immersion assay but not using other assays of thermal sensitivity. This could reflect differences in heat intensities between the assays, the surface area of tissue heated, the type of tissue heated, or the relative contribution of spinal versus supraspinal influences to 
the scored behaviors. Indeed, mice missing the thermosensor TRPV1 also had thermosensory phenotypes that were dependent on the behavioral test and temperature used (Caterina et al., 2000). For example, $\operatorname{Tr} p v 1^{-1-}$ mice had a significant deficit in the tail immersion assay at $50^{\circ} \mathrm{C}$ but no phenotype in the hot plate assay at $50^{\circ} \mathrm{C}$ or the Hargreaves assay at most intensity levels tested.

Curiously, we observed enhanced thermal and mechanical sensitivity following CFA inflammation but only enhanced thermal sensitivity following nerve injury in $N t 5 e^{-1-}$ mice and in $\mathrm{Pap}^{-1-}$ mice (Zylka et al., 2008). This differential effect on mechanical sensitization could reflect differences in how CFA and nerve injury promote mechanical sensitization, or this could reflect a "floor" effect. For example, for technical or physiological reasons, mechanical sensitization may be at maximal levels following nerve injury in all genotypes.

Adenosine is rapidly removed from the extracellular space by nucleoside transporters and metabolic enzymes, including adenosine kinase and adenosine deaminase. Indeed, the extracellular concentration of adenosine and the antinociceptive effects of adenosine can be increased by pharmacologically inhibiting these transporters or metabolic enzymes (Keil and DeLander, 1992; Poon and Sawynok, 1998; Lavand'homme and Eisenach, 1999; Kowaluk and Jarvis, 2000; Jarvis et al., 2002). In addition, a metabolically stable analog of adenosine, but not adenosine itself, had acute thermal antinociceptive effects in mice (Post, 1984). Other groups found that stable analogs of adenosine or high doses of adenosine had additional antinociceptive effects in rodents and humans (for review, see Sawynok, 2007) (Lee and Yaksh, 1996; Belfrage et al., 1999; Gomes et al., 1999; Eisenach et al., 2002; Hayashida et al., 2005). The use of stable adenosine analogs or high doses of adenosine provides an empirical means to bypass or overwhelm, respectively, the enzymes that inactivate adenosine.

We hypothesized that spinally injected AMP might be hydrolyzed by endogenous NT5E and the liberated adenosine would reduce thermal sensitivity. However, we found that intrathecal injection of AMP alone had no effect on thermal nociception. This finding, combined with observations by others described above, suggested that ectonucleotidase-generated adenosine might be metabolized before it could detectably affect thermal nociception. Indeed, by coinjecting AMP with the adenosine kinase inhibitor ITU, we were able to "unmask" an acute thermal antinociceptive effect of AMP. This antinociceptive effect was blunted by $\sim 50 \%$ in $N t 5 e^{-1-}$ mice and eliminated in $A_{1} R^{-1-}$ mice, indicating a partial dependence on NT5E activity and complete dependence on $A_{1} R$ activation. Similarly, we found that coinjection of AMP with the adenosine deaminase inhibitor 2-deoxycoformycin reduced noxious thermal sensitivity when acutely injected (intrathecally), whereas 2-deoxycoformycin alone was ineffective (data not shown). Together, our in vivo studies demonstrate that NT5E accounts for some, but not all, AMP hydrolytic activity in DRG and spinal cord. Future studies with pharmacological inhibitors or, more rigorously, genetic elimination of both NT5E and PAP will be needed to determine if these are the only two enzymes with ecto- 5 ' -nucleotidase activity in nociceptive circuits. In addition, it might be possible to harness NT5E to make adenosine for the treatment of chronic pain.

In the skin, NT5E is found on microvessels and is used as a cell-surface marker of skin stem cells (Hoogduijn et al., 2006; Niemelä et al., 2008). Aside from reports such as these, the spatial distribution of NT5E in the skin has not been well studied. We found NT5E on nociceptive axon terminals in the epidermis, on cells of the superficial dermis, and on keratinocytes throughout the epidermis, including cells in the stratum basalis. Keratinocytes release nucleotides, particularly ATP, when stimulated mechanically or thermally. In turn, nucleotides activate purinergic receptors on sensory endings in the skin and regulate thermal selection behavior (Dixon et al., 1999; Koizumi et al., 2004; Moqrich et al., 2005; Shimizu et al., 2005; Mandadi et al., 2009). Nucleotide signaling can be terminated through receptor desensitization or nucleotide metabolism. ENTPD1 (CD39, NTPDase1) is found on epidermal Langerhans cells and hydrolyzes keratinocyte-derived ATP and ADP to AMP (Mizumoto et al., 2002). Enzymes with AMP hydrolytic activity are present on epidermal keratinocytes (Klaushofer and Böck, 1974). Our studies suggest that NT5E is well localized to catalyze this final step of nucleotide hydrolysis in the skin, namely hydrolysis of AMP to adenosine.

At present, it is unclear how NT5E-generated adenosine might regulate physiological processes in the skin. Adenosine could activate all four adenosine receptors $\left(A_{1} R, A_{2 A} R, A_{2 B} R\right.$, $A_{3} R$ ), as all four receptors are found in skin keratinocytes (Braun et al., 2006), and some are found on skin microvessels. Confusingly, some studies suggest adenosine has proliferative effects on keratinocytes while others describe antiproliferative effects (Cook et al., 1995; Braun et al., 2006). These discrepancies could be due to the concentration of adenosine used or to the receptor subtypes that are activated. For example, adenosine produces cutaneous hyperalgesia when injected peripherally via activation of $\mathrm{A}_{2}$ receptors (Taiwo and Levine, 1990), whereas selective activation of $A_{1} R$ in the periphery is antinociceptive (Aley et al., 1995). Interestingly, at low concentrations, adenosine causes vasodilation in skin microcirculation and this response is $\mathrm{A}_{1} \mathrm{R}$ - and temperaturedependent (Stojanov and Proctor, 1989, 1990). In contrast, at high concentrations, adenosine produces temperature-independent vasoconstriction through $\mathrm{A}_{2} \mathrm{R}$ (Stojanov and Proctor, 1989, 1990). Considering the role of nucleotides in mediating thermal selection behavior and the importance of the peripheral vasculature in thermoregulation, NT5E could provide a molecular and biochemical link between nucleotide-dependent temperature sensation in the skin and adenosine-dependent vascular responses.

\section{References}

Aley KO, Green PG, Levine JD (1995) Opioid and adenosine peripheral antinociception are subject to tolerance and withdrawal. J Neurosci 15:8031-8038.

Bantel C, Tobin JR, Li X, Childers SR, Chen SR, Eisenach JC (2002) Intrathecal adenosine following spinal nerve ligation in rat: short residence time in cerebrospinal fluid and no change in $\mathrm{A}(1)$ receptor binding. Anesthesiology 96:103-108.

Belfrage M, Segerdahl M, Arnér S, Sollevi A (1999) The safety and efficacy of intrathecal adenosine in patients with chronic neuropathic pain. Anesth Analg 89:136-142.

Bennett DL, Dmietrieva N, Priestley JV, Clary D, McMahon SB (1996) trkA, CGRP and IB4 expression in retrogradely labelled cutaneous and visceral primary sensory neurones in the rat. Neurosci Lett 206:33-36.

Boison D (2008) Adenosine as a neuromodulator in neurological diseases. Curr Opin Pharmacol 8:2-7.

Bradbury EJ, Burnstock G, McMahon SB (1998) The expression of P2X3 purinoreceptors in sensory neurons: effects of axotomy and glial-derived neurotrophic factor. Mol Cell Neurosci 12:256-268.

Braun M, Lelieur K, Kietzmann M (2006) Purinergic substances promote murine keratinocyte proliferation and enhance impaired wound healing in mice. Wound Repair Regen 14:152-161.

Burnstock G (2007) Physiology and pathophysiology of purinergic neurotransmission. Physiol Rev 87:659-797.

Callahan BL, Gil AS, Levesque A, Mogil JS (2008) Modulation of mechanical and thermal nociceptive sensitivity in the laboratory mouse by behavioral state. J Pain 9:174-184. 
Campagnola L, Wang H, Zylka MJ (2008) Fiber-coupled light-emitting diode for localized photostimulation of neurons expressing channelrhodopsin-2. J Neurosci Methods 169:27-33.

Campbell JN, Meyer RA (2006) Mechanisms of neuropathic pain. Neuron 52:77-92.

Casals-Díaz L, Vivó M, Navarro X (2009) Nociceptive responses and spinal plastic changes of afferent C-fibers in three neuropathic pain models induced by sciatic nerve injury in the rat. Exp Neurol 217:84-95.

Caterina MJ, Schumacher MA, Tominaga M, Rosen TA, Levine JD, Julius D (1997) The capsaicin receptor: a heat-activated ion channel in the pain pathway. Nature 389:816-824.

Caterina MJ, Leffler A, Malmberg AB, Martin WJ, Trafton J, Petersen-Zeitz KR, Koltzenburg M, Basbaum AI, Julius D (2000) Impaired nociception and pain sensation in mice lacking the capsaicin receptor. Science 288:306-313.

Cavanaugh DJ, Lee H, Lo L, Shields SD, Zylka MJ, Basbaum AI, Anderson DJ (2009) Distinct subsets of unmyelinated primary sensory fibers mediate behavioral responses to noxious thermal and mechanical stimuli. Proc Natl Acad Sci U S A 106:9075-9080.

Colgan SP, Eltzschig HK, Eckle T, Thompson LF (2006) Physiological roles for ecto-5'-nucleotidase (CD73). Purinergic Signal 2:351-360.

Colmant HJ (1959) Aktivitatsschwankungen der sauren Phosphatase im Ruckenmark und den Spinalganglien der Ratte nach Durchschneidung des Nervus ischiadicus. Arch Psychiat Nervnekr 199:60-71.

Cook PW, Ashton NM, Pittelkow MR (1995) Adenosine and adenine nucleotides inhibit the autonomous and epidermal growth factor-mediated proliferation of cultured human keratinocytes. J Invest Dermatol 104:976-981.

Costigan M, Befort K, Karchewski L, Griffin RS, D’Urso D, Allchorne A, Sitarski J, Mannion JW, Pratt RE, Woolf CJ (2002) Replicate highdensity rat genome oligonucleotide microarrays reveal hundreds of regulated genes in the dorsal root ganglion after peripheral nerve injury. BMC Neurosci 3:16.

Csillik B, Knyihar-Csillik E (1986) The protean gate: structure and plasticity of the primary nociceptive analyzer. Budapest: Akademiai Kiado.

Cunha TM, Verri WA Jr, Vivancos GG, Moreira IF, Reis S, Parada CA, Cunha FQ, Ferreira SH (2004) An electronic pressure-meter nociception paw test for mice. Braz J Med Biol Res 37:401-407.

Davis-Taber RA (2006) Transcriptional profiling of dorsal root ganglia in a neuropathic pain model using microarray and laser capture microdissection. Drug Dev Res 67:308-330.

Dixon CJ, Bowler WB, Littlewood-Evans A, Dillon JP, Bilbe G, Sharpe GR, Gallagher JA (1999) Regulation of epidermal homeostasis through P2Y2 receptors. Br J Pharmacol 127:1680-1686.

Dussor G, Koerber HR, Oaklander AL, Rice FL, Molliver DC (2009) Nucleotide signaling and cutaneous mechanisms of pain transduction. Brain Res Rev 60:24-35.

Eisenach JC, Hood DD, Curry R (2002) Preliminary efficacy assessment of intrathecal injection of an American formulation of adenosine in humans. Anesthesiology 96:29-34.

Fairbanks CA (2003) Spinal delivery of analgesics in experimental models of pain and analgesia. Adv Drug Deliv Rev 55:1007-1041.

Gomes JA, Li X, Pan HL, Eisenach JC (1999) Intrathecal adenosine interacts with a spinal noradrenergic system to produce antinociception in nerveinjured rats. Anesthesiology 91:1072-1079.

Hargreaves K, Dubner R, Brown F, Flores C, Joris J (1988) A new and sensitive method for measuring thermal nociception in cutaneous hyperalgesia. Pain 32:77-88.

Hayashida M, Fukuda K, Fukunaga A (2005) Clinical application of adenosine and ATP for pain control. J Anesth 19:225-235.

Hoogduijn MJ, Gorjup E, Genever PG (2006) Comparative characterization of hair follicle dermal stem cells and bone marrow mesenchymal stem cells. Stem Cells Dev 15:49-60.

Hua X, Erikson CJ, Chason KD, Rosebrock CN, Deshpande DA, Penn RB, Tilley SL (2007) Involvement of Al adenosine receptors and neural pathways in adenosine-induced bronchoconstriction in mice. Am J Physiol Lung Cell Mol Physiol 293:L25-32.

Inoue M, Rashid MH, Fujita R, Contos JJ, Chun J, Ueda H (2004) Initiation of neuropathic pain requires lysophosphatidic acid receptor signaling. Nat Med 10:712-718.

Jarvis MF, Mikusa J, Chu KL, Wismer CT, Honore P, Kowaluk EA, McGaraughty S (2002) Comparison of the ability of adenosine kinase inhibitors and adenosine receptor agonists to attenuate thermal hyperalgesia and reduce motor performance in rats. Pharmacol Biochem Behav 73:573-581.

Johansson B, Halldner L, Dunwiddie TV, Masino SA, Poelchen W, GiménezLlort L, Escorihuela RM, Fernández-Teruel A, Wiesenfeld-Hallin Z, Xu XJ, Hårdemark A, Betsholtz C, Herlenius E, Fredholm BB (2001) Hyperalgesia, anxiety, and decreased hypoxic neuroprotection in mice lacking the adenosine A1 receptor. Proc Natl Acad Sci U S A 98:9407-9412.

Julius D, Basbaum AI (2001) Molecular mechanisms of nociception. Nature 413:203-210.

Keil GJ 2nd, DeLander GE (1992) Spinally-mediated antinociception is induced in mice by an adenosine kinase-, but not by an adenosine deaminase-, inhibitor. Life Sci 51:PL171-176.

Klaushofer K, Böck P (1974) Studies on 5'-nucleotidase histochemistry. II. Differences in $5^{\prime}$-nucleotidase activity in stratified squamous epithelia and skin appendages of mouse, rat and guinea pig. Histochemistry 40:39-49.

Koizumi S, Fujishita K, Inoue K, Shigemoto-Mogami Y, Tsuda M (2004) $\mathrm{Ca}^{2+}$ waves in keratinocytes are transmitted to sensory neurons: the involvement of extracellular ATP and P2Y2 receptor activation. Biochem J 380:329-338

Kowaluk EA, Jarvis MF (2000) Therapeutic potential of adenosine kinase inhibitors. Expert Opin Investig Drugs 9:551-564.

Lao LJ, Kumamoto E, Luo C, Furue H, Yoshimura M (2001) Adenosine inhibits excitatory transmission to substantia gelatinosa neurons of the adult rat spinal cord through the activation of presynaptic $\mathrm{A}(1)$ adenosine receptor. Pain 94:315-324.

Lavand'homme PM, Eisenach JC (1999) Exogenous and endogenous adenosine enhance the spinal antiallodynic effects of morphine in a rat model of neuropathic pain. Pain 80:31-36.

Lawson SN, Crepps B, Perl ER (2002) Calcitonin gene-related peptide immunoreactivity and afferent receptive properties of dorsal root ganglion neurones in guinea-pigs. J Physiol 540:989-1002.

Ledoux S, Runembert I, Koumanov K, Michel JB, Trugnan G, Friedlander G (2003) Hypoxia enhances Ecto-5'-Nucleotidase activity and cell surface expression in endothelial cells: role of membrane lipids. Circ Res 92:848-855.

Lee YW, Yaksh TL (1996) Pharmacology of the spinal adenosine receptor which mediates the antiallodynic action of intrathecal adenosine agonists. J Pharmacol Exp Ther 277:1642-1648.

Li J, Perl ER (1994) Adenosine inhibition of synaptic transmission in the substantia gelatinosa. J Neurophysiol 72:1611-1621.

Li J, Perl ER (1995) ATP modulation of synaptic transmission in the spinal substantia gelatinosa. J Neurosci 15:3357-3365.

Lumpkin EA, Caterina MJ (2007) Mechanisms of sensory transduction in the skin. Nature 445:858-865.

Mandadi S, Sokabe T, Shibasaki K, Katanosaka K, Mizuno A, Moqrich A, Patapoutian A, Fukumi-Tominaga T, Mizumura K, Tominaga M (2009) TRPV3 in keratinocytes transmits temperature information to sensory neurons via ATP. Pflugers Arch 458:1093-1102.

Matsuoka I, Ohkubo S (2004) ATP- and adenosine-mediated signaling in the central nervous system: adenosine receptor activation by ATP through rapid and localized generation of adenosine by ecto-nucleotidases. J Pharmacol Sci 94:95-99.

Mizumoto N, Kumamoto T, Robson SC, Sévigny J, Matsue H, Enjyoji K, Takashima A (2002) CD39 is the dominant Langerhans cell-associated ecto-NTPDase: modulatory roles in inflammation and immune responsiveness. Nat Med 8:358-365.

Molliver DC, Wright DE, Leitner ML, Parsadanian AS, Doster K, Wen D, Yan Q, Snider WD (1997) IB4-binding DRG neurons switch from NGF to GDNF dependence in early postnatal life. Neuron 19:849-861.

Moqrich A, Hwang SW, Earley TJ, Petrus MJ, Murray AN, Spencer KS, Andahazy M, Story GM, Patapoutian A (2005) Impaired thermosensation in mice lacking TRPV3, a heat and camphor sensor in the skin. Science 307:1468-1472.

Nagy JI, Daddona PE (1985) Anatomical and cytochemical relationships of adenosine deaminase-containing primary afferent neurons in the rat. Neuroscience 15:799-813.

Niemelä J, Ifergan I, Yegutkin GG, Jalkanen S, Prat A, Airas L (2008) IFNbeta regulates $\mathrm{CD} 73$ and adenosine expression at the blood-brain barrier. Eur J Immunol 38:2718-2726. 
Patel MK, Pinnock RD, Lee K (2001) Adenosine exerts multiple effects in dorsal horn neurones of the adult rat spinal cord. Brain Res 920:19-26.

Patterson SL, Sluka KA, Arnold MA (2001) A novel transverse push-pull microprobe: in vitro characterization and in vivo demonstration of the enzymatic production of adenosine in the spinal cord dorsal horn. J Neurochem 76:234-246.

Poon A, Sawynok J (1998) Antinociception by adenosine analogs and inhibitors of adenosine metabolism in an inflammatory thermal hyperalgesia model in the rat. Pain 74:235-245.

Post C (1984) Antinociceptive effects in mice after intrathecal injection of 5' -N-ethylcarboxamide adenosine. Neurosci Lett 51:325-330.

Rau KK, McIlwrath SL, Wang H, Lawson JJ, Jankowski MP, Zylka MJ, Anderson DJ, Koerber HR (2009) Mrgprd enhances excitability in specific populations of cutaneous murine polymodal nociceptors. J Neurosci 29:8612-8619.

Rice FL, Fundin BT, Arvidsson J, Aldskogius H, Johansson O (1997) Comprehensive immunofluorescence and lectin binding analysis of vibrissal follicle sinus complex innervation in the mystacial pad of the rat. J Comp Neurol 385:149-184.

Salter MW, Henry JL (1985) Effects of adenosine 5' -monophosphate and adenosine $5^{\prime}$-triphosphate on functionally identified units in the cat spinal dorsal horn. Evidence for a differential effect of adenosine 5' triphosphate on nociceptive vs non-nociceptive units. Neuroscience 15:815-825.

Sawynok J (2007) Adenosine and ATP receptors. Handb Exp Pharmacol $177: 309-328$

Scott TG (1967) The distribution of $5^{\prime}$-nucleotidase in the brain of the mouse. J Comp Neurol 129:97-114.

Shields SD, Eckert WA 3rd, Basbaum AI (2003) Spared nerve injury model of neuropathic pain in the mouse: a behavioral and anatomic analysis. J Pain 4:465-470.

Shimizu I, Iida T, Guan Y, Zhao C, Raja SN, Jarvis MF, Cockayne DA, Caterina MJ (2005) Enhanced thermal avoidance in mice lacking the ATP receptor P2X3. Pain 116:96-108.

Sowa NA, Vadakkan KI, Zylka MJ (2009) Recombinant mouse PAP has $\mathrm{pH}$-dependent ectonucleotidase activity and acts through $\mathrm{A}(1)$ adenosine receptors to mediate antinociception. PLoS ONE 4:e4248.

Stojanov I, Proctor KG (1989) Pharmacological evidence for A1 and A2 adenosine receptors in the skin microcirculation. Circ Res 65:176-184.

Stojanov I, Proctor KG (1990) Temperature-sensitive adenosine-mediated vasoconstriction in the skin microcirculation. J Pharmacol Exp Ther 253:1083-1089.

Suran AA (1974) 5' -Nucleotidase and an acid phosphatase of spinal cord.
Comparative histochemistry and specificity of the enzymes in mouse and cat spinal cords. Cytologic localization in mouse substantia gelatinosa. J Histochem Cytochem 22:802-811.

Synnestvedt K, Furuta GT, Comerford KM, Louis N, Karhausen J, Eltzschig HK, Hansen KR, Thompson LF, Colgan SP (2002) Ecto-5'-nucleotidase (CD73) regulation by hypoxia-inducible factor-1 mediates permeability changes in intestinal epithelia. J Clin Invest 110:993-1002.

Taiwo YO, Levine JD (1990) Direct cutaneous hyperalgesia induced by adenosine. Neuroscience 38:757-762.

Taylor AM, Peleshok JC, Ribeiro-da-Silva A (2009) Distribution of P2X(3)immunoreactive fibers in hairy and glabrous skin of the rat. J Comp Neurol 514:555-566.

Taylor-Blake B, Zylka MJ (2010) Prostatic acid phosphatase is expressed in peptidergic and nonpeptidergic nociceptive neurons of mice and rats. PLoS One 5:e8674.

Thompson LF, Eltzschig HK, Ibla JC, Van De Wiele CJ, Resta R, MoroteGarcia JC, Colgan SP (2004) Crucial role for ecto-5'-nucleotidase (CD73) in vascular leakage during hypoxia. J Exp Med 200:1395-1405.

Tsuda M, Inoue K, Salter MW (2005) Neuropathic pain and spinal microglia: a big problem from molecules in "small" glia. Trends Neurosci 28:101-107.

Van Etten RL (1982) Human prostatic acid phosphatase: a histidine phosphatase. Ann N Y Acad Sci 390:27-51.

Vihko P (1978) Characterization of the principal human prostatic acid phosphatase isoenzyme, purified by affinity chromatography and isoelectric focusing. Part II. Clin Chem 24:1783-1787.

Wang HF, Robertson B, Grant G (1998) Anterograde transport of horseradish-peroxidase conjugated isolectin B4 from Griffonia simplicifolia I in spinal primary sensory neurons of the rat. Brain Res 811:34-39.

Wu WP, Hao JX, Halldner L, Lövdahl C, DeLander GE, Wiesenfeld-Hallin Z, Fredholm BB, Xu XJ (2005) Increased nociceptive response in mice lacking the adenosine A1 receptor. Pain 113:395-404.

Zimmermann H (1992) 5'-Nucleotidase: molecular structure and functional aspects. Biochem J 285:345-365

Zimmermann H (2006) Ectonucleotidases in the nervous system. Novartis Found Symp 276:113-128; discussion 128-130, 233-237, 275-281.

Zylka MJ, Rice FL, Anderson DJ (2005) Topographically distinct epidermal nociceptive circuits revealed by axonal tracers targeted to Mrgprd. Neuron 45:17-25.

Zylka MJ, Sowa NA, Taylor-Blake B, Twomey MA, Herrala A, Voikar V, Vihko P (2008) Prostatic acid phosphatase is an ectonucleotidase and suppresses pain by generating adenosine. Neuron 60:111-122. 